\title{
Herbal Extract Decolourization Device Using Activated Carbon
}

\author{
Teh Liam Chee $^{a^{*}}$, Rozilawati Abdul Gaffar, ${ }^{\text {b }}$ Fadzilah Adibah Abdul Majid $^{\text {b }}$, Mohammad Roji Sarmidi ${ }^{\text {b }}$ \\ ${ }^{a}$ Department of Bioprocess Engineering, Faculty of Chemical Engineering, Universiti Teknologi Malaysia, 81310 UTM Johor Bahru, Johor, \\ Malaysia \\ ${ }^{b}$ Institute of Bioproduct Development (IBD), Universiti Teknologi Malaysia, 81310 UTM Johor Bahru, Johor, Malaysia
}

*Corresponding author: Icteh86@gmail.com

Article history

Received :10 September 2012

Received in revised form $: 27$

December 2012

Accepted :12 February 2013

\section{Graphical abstract}

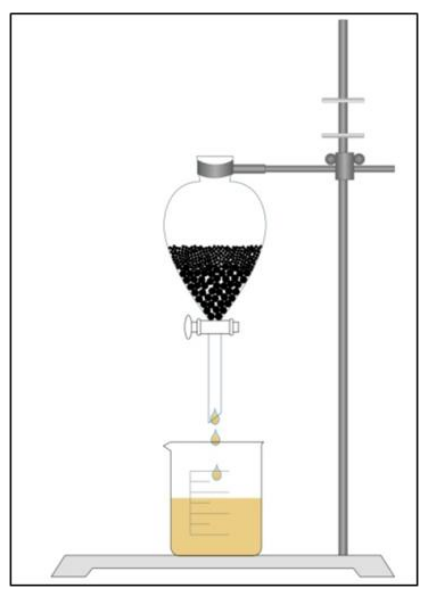

\section{Abstract}

Herbal extracts are known for their antioxidant, antimicrobial, and anti-inflammatory properties. However, the intense colour caused by their phenolic content and dark-coloured compounds may spoil the final product's appearance. To remedy that, this study was undertaken to design a decolourization device to eliminate the intense colour of herbal extracts while retaining their beneficial properties. Batch experiments have been conducted to study decolourization and its effect on extract quality. From there, a decolourization device has been devised using activated carbon. Operating at optimum conditions, the device was able reduce $81 \%$ of the total phenolic content of cashew leaf extracts while retaining $88 \%$ of its radical scavenging capacity. Furthermore, the device is able to re-design the extract's colour to fulfill the end-user's needs by manipulating the contact period. The design of this device best fits Langmuir isotherm which demonstrates monolayer coverage of adsorbate at the outer surface of activated carbon.

Keywords: Activated carbon; adsorption; herbal extract; Langmuir Isotherm; decolourization

\section{Abstrak}

Ekstrak herba telah dikenali untuk kosmeseutikal dan sifat nutraseutikalnya seperti antioksidan, antimikrob, anti radang dan lain-lain. Walau bagaimanapun, warna yang pekat mungkin merosakkan penampilan produk disebabkan kandungan fenolik dan komponen warna gelap yang lain. Penyelidikan ini bertujuan untuk merekacipta satu alat pelunturan warna untuk menghilangkan warna pekat ekstrak tumbuhan sambil mengekalkan sifat berfaedah dengan menggunakan karbon teraktif. Eksperimen Batch telah dijalankan untuk mengkaji pelunturan warna dan prestasi kualiti ekstrak. Keadaan operasi yang optimum untuk $100 \mathrm{~mL}$ extrak daun gajus adalah menggunakan $5 \mathrm{~g}$ serbuk karbon teraktif dan $5 \mathrm{~g}$ butiran karbon teraktif, pada suhu $25^{\circ} \mathrm{C}$ dan 10 minit masa sentuhan. Keadaan ini menurunkan $81 \%$ jumlah kandungan fenol dan mengekalkan $88 \%$ RSC estrak daun gajus. Reka bentuk sistem ini paling sesuai diterangkan dengan Langmuir isoterma yang menunjukkan liputan monolayer komponen fenolik dan warna gelap pada permukaan luar karbon teraktif. Kajian ini adalah percubaan pertama untuk menunjukkan potensi menggunakan karbon teraktif untuk melunturkan warna ekstrak herba. Satu kelebihan rekabentuk alat ini adalah bahawa pelunturan warna ekstrak herba boleh diubahsuai berdasarkan keperluan pengguna akhir dengan memanipulasi masa sentuhan.

Kata kunci: Karbon teraktif; adsorption; ekstrak herba; Langmuir Isoterma; pelunturan warna

\subsection{INTRODUCTION}

Consumers nowadays are keen to ask for more effective and more natural products to maintain the wellbeing of their skin. As a result, more attention has shifted to cosmeceutical products with high antioxidant properties; Properties that could slow down the process of aging and rejuvenate skin. A source of safe, natural antioxidants is food plants that are rich in phenolic compounds.

One of the challenges of developing a cosmetic formulation from plants is the intense colour of the extracts that may spoil the product's appearance. Phenolic compounds are the main contributor to the intense dark colour of the herbal extracts, making them unsuitable as an ingredient for cosmeceutical products even though they contain antioxidants and other beneficial properties. Hence, there is the pressing need to develop a procedure to eliminate the intense colour of herbal extracts while retaining their high antioxidant properties. The removal of polyphenolic compounds and their intense colour from herbal extracts using conventional methods is quite difficult without compromising the quality of the final product. For example, the use of chemicals as a bleaching agent to 
remove the extracts' colour is not welcomed by consumers. Alternatively, some sort of adsorption process could be employed to remove phenolic and other coloured compounds from herbal extracts. Indeed, such a method is commonly used to purify contaminated fluids that smells and tastes bad. For such a task, a number of decolourizing agents are currently being used in the fruit juice industry to remove phenolic compound. Such decolourizing agents include activated carbon (AC), gelatine or bentonite, casein, ion-exchange resins and polyvinylpolypyrrolidone (PVPP) [1].

$\mathrm{AC}$ is widely used as a natural and cost effective adsorbent of colours and organic substances. This is due to its outstanding adsorptive ability and its wide variety of forms to suit different processing conditions. For this reason, the capacity of AC to remove phenolic and coloured compounds in food stuff and fruit juices as well as its application in waste water treatment have been extensively studied[1-6]. That being said, decolourization of herbal extracts using AC has yet been studied. For that, an $\mathrm{AC}$ separator system was designed and tested in this study to facilitate decolourization of herbal extracts. Of the various AC's physical forms, AC in the form of powder and granular are the most commonly used. Several parameters may influence the performance of $\mathrm{AC}$ as an adsorbent. The adsorptive characteristics of AC are mainly affected by its porous structure, surface area and its surface's chemical structure [7]. Other factors such the amount of AC used, operation temperature, and contact period of the samples with AC also play a role. These parameters have been investigated in this study to optimize the conditions required for optimum decolourization of herbal extracts using the AC separator system.

Cashew leaf extracts' antimicrobial activity and antityrosinase activity can be exploited for preserving and whitening purposes respectively, and hence is a potential cosmeceutical ingredient [8], [9]. Indeed, the cashew tree is a food plant known to possess quite a few medicinal properties. The shoots of cashew are freshly eaten as 'ulam' by the Malay community especially from the east coast of peninsular Malaysia for its rejuvenating effects. Aside from that, different parts of the plant have been widely used traditionally for sore gums and toothaches, sore throats, burns and skin diseases [10], [11]. Furthermore, cashew is also used to effectively remedy diarrhea and colic. On top of that, it is considered to be gentle enough to be taken by children [11]. Besides that, it was also reported that cashew leaf extracts have antiulcerogenic effect [10]. More importantly, it was recently demonstrated that cashew leaf extracts possess strong antioxidant activities [7], thus making it well suited to be a new active ingredient in cosmetic formulation with multiple functions.

Desirable characteristics that must be kept in mind in developing the decolourization device include simplicity of operation, ease of decolourization, affordability and availability of absorption materials, and the ability to be operated at room temperature with the absence of chemicals. The core component of the decolourization device consist of two layers; the upper layer that consists of powdered activated carbon with higher surface area, and the base layer that consists of granular activated carbon that prevents leaching of the powdered activated carbon above. Since the absorbability of granular and powdered activated carbon are different, it is important to investigate the ratio of these two forms of activated carbons with respect to the decolourization performance of the device on the extract.

This study was the first attempt to decolourize herbal extracts with $\mathrm{AC}$ and investigate the effects of the ratio between the two different forms of AC (powder and granular) on decolourization. The purpose of this study was to design and optimize operating conditions for a device that decolourizes herbal extracts by AC adsorption. To this end, it was necessary to determine: (i) the optimum composition of two AC (granular and powder form) used, (ii) the respective effects of temperature and contact period on total polyphenolic content removal and antioxidant retention, and (iii) the best adsorption model (Langmuir, Freundlich, Frumkin or Temkin) to estimate AC adsorption capacity and isotherm parameters.

\subsection{MATERIAL AND METHOD}

\subsection{The Plant}

The Anacardium occidentale (Cashew) tree is easily cultivated in Malaysia predominantly alongside coastal areas. The leaves for this study were obtained from a cashew tree located near block N18 in Universiti Teknologi Malaysia (UTM).

\subsection{Raw Extract Preparation}

The cashew leaves were cleaned and left to dry for 3 to 5 days. The dried leaves were then pulverized to powder form (50-70 mesh) and stored in a dry place prior to extraction. The crude extract was prepared by Soxhlet extraction using $95 \%$ ethanol $(250 \mathrm{~mL})$ for 18 hours at $78-80{ }^{\circ} \mathrm{C}$. After that, the extracts were kept for further use in a cold dry place.

\subsection{Determination of Adsorption Efficiency}

The adsorption efficiency of AC on dark-coloured compounds in the raw extracts were evaluated by determining the percentage decrease of the absorbance at $420 \mathrm{~nm}$; the higher the adsorption percentage, the higher the amount of dark-coloured compounds being removed. At the same time, it also indicates how light the extract's colour has become. A graph of adsorption (\%) versus contact time for different compositions of activated carbon was plotted.

\subsection{Antioxidant Assay}

The decolourized sample extracts were oven-dried after the decolourization treatment. The dried solids were then diluted in dimethyl sulfoxide (DMSO) into solutions of concentrations $1 \mathrm{mg} / \mathrm{mL}$ and $10 \mathrm{mg} / \mathrm{mL}$. After that, $5 \mu \mathrm{L}$ of these test sample extracts were mixed with $95 \mu \mathrm{L}$ of 1,1-Diphenyl-2picrylhydrazyl, (DPPH, $300 \mathrm{M})$ in ethanol. The mixtures were incubated at $37{ }^{\circ} \mathrm{C}$ for $30 \mathrm{~min}$, and then the absorbances were measured at $570 \mathrm{~nm}$. From there, the Radical Scavenging Capacity (RSC), expressed as a percentage was calculated. Ascorbic acid was used as a standard [7], [12]. A graph of RSC percentage for extracts with $1 \mathrm{mg} / \mathrm{mL}$ and $10 \mathrm{mg} / \mathrm{mL}$ concentration treated by different compositions of activated carbon versus contact time was plotted.

\subsection{Determination of Optimum Contact Period and Activated Carbon Composition}

The decolourization device was assembled as presented in Figure 1. The original absorbance of the sample extracts was measured at $420 \mathrm{~nm}$ before any treatments were carried out. With raw extracts of natural $\mathrm{pH}$ and at room temperature $\left(25^{\circ} \mathrm{C}\right)$, $100 \mathrm{~mL}$ of raw extracts were inserted into the device layered with $\mathrm{ACs}$ (powdered $\mathrm{AC}$ layered above granular $\mathrm{AC}$ ). The ratio of powdered $\mathrm{AC}$ to granular $\mathrm{AC}$ was manipulated to $0: 1,1: 1$, and 2:1, with the amount of granular AC maintained at $5 \mathrm{~g}$ in all 
three. The amount of granular AC was not manipulated because a previous study has shown that there were no increment in adsorption efficiency of dark-coloured compounds even in higher amounts [1]. For each of different AC ratios, raw extracts were left in the device for contact periods of 10, 20, 30, 40, 50, and 60 minutes. After the treatments, the treated sample extracts were measured their absorbance at $420 \mathrm{~nm}$. The optimum contact period and composition of AC for adsorption efficiency were determined from the results.

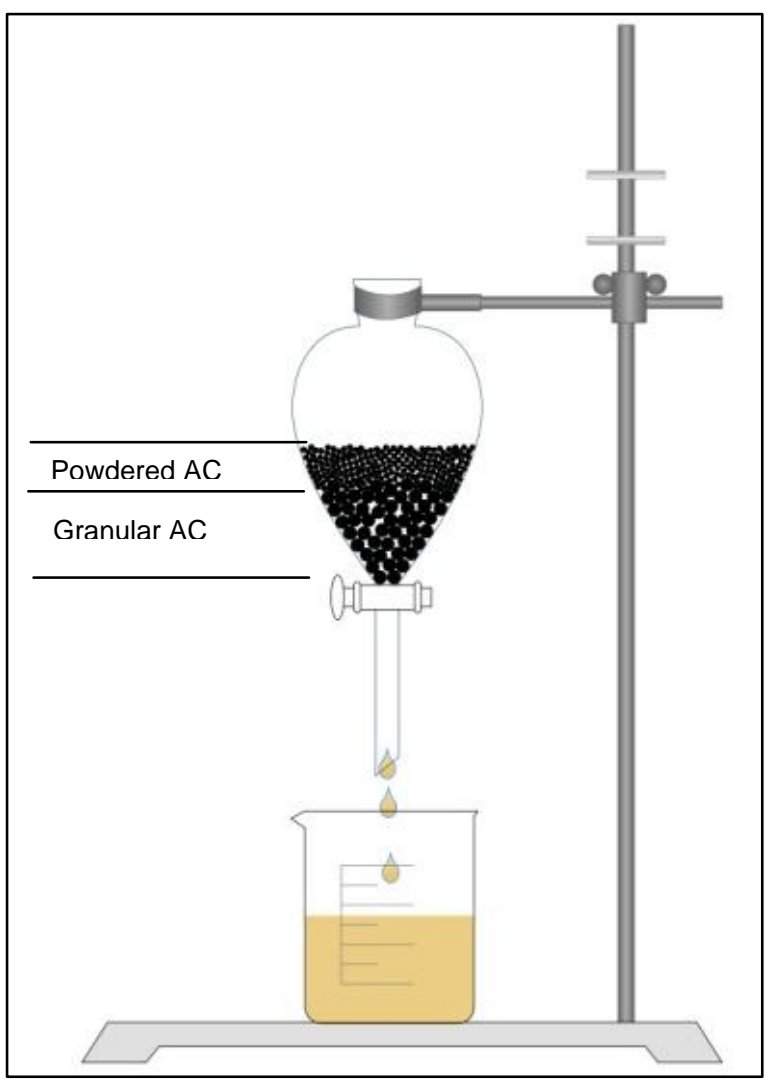

Figure 1 Diagram of herbal extract decolourization device

\subsection{Quality Analysis}

All treated raw extracts were dried and then dissolved into concentrations of $1 \mathrm{mg} / \mathrm{mL}$ and $10 \mathrm{mg} / \mathrm{mL}$. The quality of the treated sample solutions was determined by antioxidant analysis. The optimum operating conditions for decolourization device were determined from the analysis.

\subsection{Determination of Isothermal Model}

Linearized graphs were plotted to determine the adsorption isotherm that best fits the designed decolourization device. The graph with model that best fits the system. All the calculations for each isotherm were based on the following equations [13].

$$
\text { Langmuir : } \quad \frac{A_{e}}{q_{e}}=\frac{1}{b Q^{o}}+\frac{A_{e}}{Q^{o}}
$$

$\mathrm{Q}^{\mathrm{o}}$ ((a.u.) $\mathrm{m}^{3}$ sample extract $/ \mathrm{kg} \mathrm{AC}$ ) is the amount of adsorption corresponding to monolayer coverage.

Both $b$ and $Q^{o}$ were obtained from linearized plots of $\left(\mathrm{A}_{\mathrm{e}} / \mathrm{q}_{\mathrm{e}}\right)$ versus $A_{e}$.

Freundlich : $\quad \ln \mathrm{q}_{\mathrm{e}}=\ln \mathrm{K}_{\mathrm{f}}+\frac{1}{\mathrm{n}} \ln \mathrm{A}_{\mathrm{e}}$

Where

$\mathrm{K}_{\mathrm{f}}$ (a.u.) $\mathrm{m}^{3}$ sample extract $/ \mathrm{kg} \mathrm{AC}$

$1 / \mathrm{n}$ is the Freundlich constants

Both $\mathrm{K}_{\mathrm{f}}$ and $1 / \mathrm{n}$ were obtained from linearized plots of $\ln$ $\mathrm{q}_{\mathrm{e}}$ versus $\ln \mathrm{A}_{\mathrm{e}}$.

Frumkin: $\quad \mathrm{q}_{\mathrm{e}}=\mathrm{n}_{\mathrm{T}} \ln \mathrm{K}_{\mathrm{T}}+\mathrm{n}_{\mathrm{T}} \ln \mathrm{A}_{\mathrm{e}}$

Where $\mathrm{n}_{\mathrm{T}}$ and $\mathrm{K}_{\mathrm{T}}$ are the Frumkin constants.

Both $\mathrm{n}_{T}$ and $\mathrm{K}_{\mathrm{T}}$ were obtained from linearized plots of $\mathrm{q}_{\mathrm{e}}$ versus $\ln \mathrm{A}_{\mathrm{e}}$.

$$
\text { Temkin: } \mathrm{q}_{\mathrm{e}}=\mathrm{A}+\mathrm{B} \ln \left(\frac{\mathrm{A}_{\mathrm{e}}}{\mathrm{q}_{\mathrm{e}}}\right)
$$

Where A and B are the Temkin constants.

Both $\mathrm{A}$ and $\mathrm{B}$ were obtained from linearized plots of $\mathrm{q}_{\mathrm{e}}$ versus $\left(\ln A_{e} / q_{e}\right)$

\subsection{RESULT AND DISCUSSIONS}

\subsection{Optimum Contact Period and Activated Carbon Composition}

From section 2.5, it was found that an AC ratio of 2:1 (10 g powdered $\mathrm{AC}, 5 \mathrm{~g}$ granular $\mathrm{AC}$ ) and at a contact period of 10 min lead to the highest adsorption efficiency (99\%). In fact, 10 min was always the most efficient contact period for all AC compositions as illustrated in Figure 2. Evidently, a longer contact period would unnecessarily prolong the process of obtaining similar results and may affect the extracts' quality [4]. For AC composition, it would appear that the lower the powdered $\mathrm{AC}$ content, the lower the adsorption efficiency. AC compositions of 1:1 (5 g powdered AC, $5 \mathrm{~g}$ granular $\mathrm{AC}$ ) yielded an efficiency of $93 \%$ while the AC ratio of 0:1 $(0 \mathrm{~g}$ powdered AC, $5 \mathrm{~g}$ granular AC) yielded $13 \%$ only. The decrease of adsorption efficiency is due to the decrease of the number of adsorption sites [1], [4].

The differences in colours of the treated samples are shown in Figure 3. To the naked eye, it would seem that the effects of AC composition on treated sample colours of 1:1 and 2:1 are similar while $0: 1$ is a lot darker than the other two. Together with a previous study that established that higher amounts of granular AC invoked no increment in adsorption efficiency of dark-coloured compounds [1], the results of the current study agrees with another study that powdered AC are more suitable for colour adsorption in terms of adsorption efficiency [14].

Where

b (1/a.u.) is the Langmuir constant 


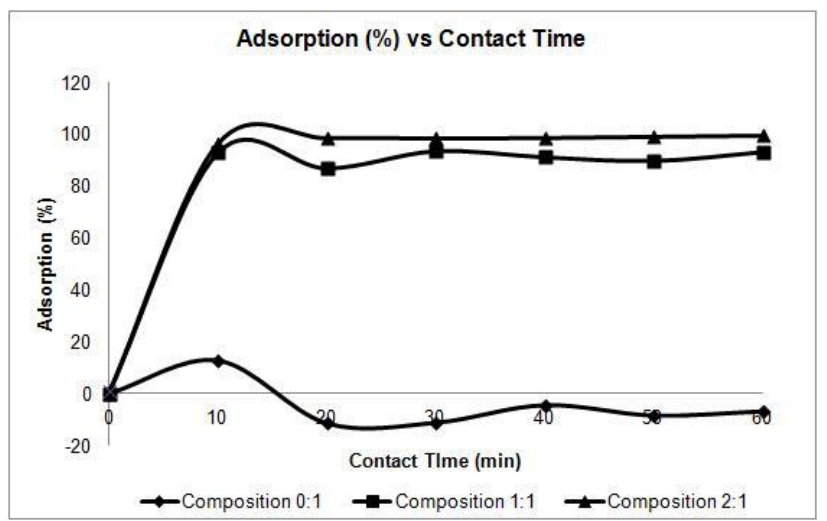

Figure 2 Graph Adsorption (\%) versus Contact Time for different composition of activated carbon

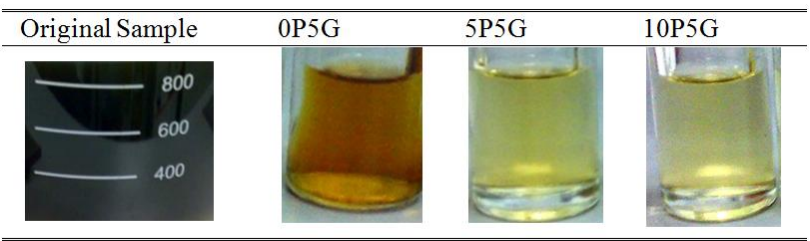

Figure 3 The colour of cashew leaves extract before and after 10 minutes contact time within the device

\subsection{Quality of Treated Extract}

The results (Figure $4 \mathrm{a}$ and $4 \mathrm{~b}$ ) suggest that antioxidant activity (the ability to scavenge free radicals) increases with sample concentration. Samples treated with the device with AC composition of $0: 1$ and $1: 1$ were able to retain $85-88 \%$ of their ability to scavenge free radicals. On the other hand, the device with AC composition of 2:1 reduced the sample's ability to scavenge free radicals to an average of $45 \%$ only. Due to the fact that the device with $\mathrm{AC}$ composition of 1:1 was able to very stably and efficiently reduce sample colour (93\%) while maintaining high antioxidant activity, it was chosen as the best AC composition for the device to adsorb dark-coloured compounds.
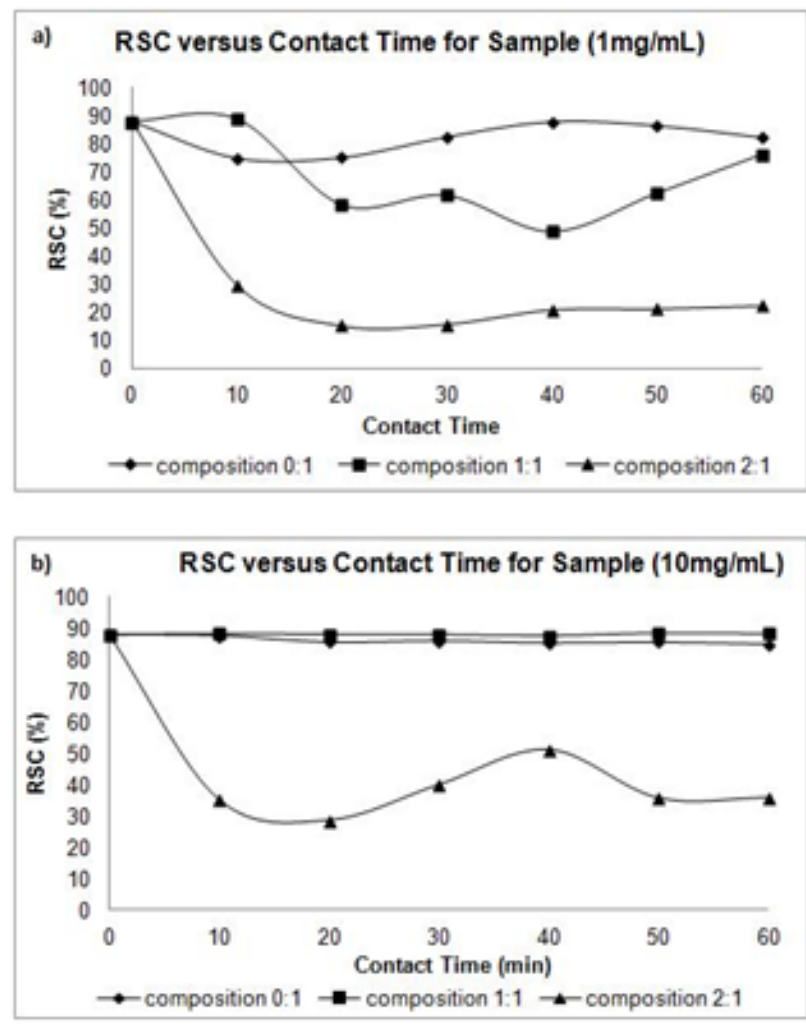

Figure 4 Graph RSC (\%) for (a) $1 \mathrm{mg} / \mathrm{mL}$ and (b) $10 \mathrm{mg} / \mathrm{mL}$ samples versus contact time for different composition of activated carbon

\subsection{Isotherms Model}

The parameters of isotherm equations (Langmuir, Freundlich, Frumkin and Temkin) for the adsorption of dark-colour compounds on this decolourization system's AC, the sum of error squares (SSE) and $\mathrm{R}$ values were calculated by using linear regression analysis (Figure 5 and Table 1). The isotherm model that has the highest $\mathrm{R}$ value and the lowest SSE value is the model that best suits the experimental data (Table 2) [1]. Of the four isotherm models, the Langmuir isotherm (Figure 5a) is found to be the best fit for the experimental data since it has the highest $\mathrm{R}$ value (0.9996) and the lowest SEE value $(2.616 \times$ $10^{7}$ ).

The results indicates that the adsorption of dark-coloured compounds by the newly designed decolourization device is linear and irreversible at the composition and temperature $\left(25^{\circ} \mathrm{C}\right)$ used [12], [13]. The Langmuir and Freundlich isotherm models have been listed in most of the previous studies as the adsorption models that is sufficient to describe the equilibrium adsorption data and determine the isotherm parameters for total phenolic content and dark-coloured compound adsorption [1, 2], $[4,5],[14,15]$. 

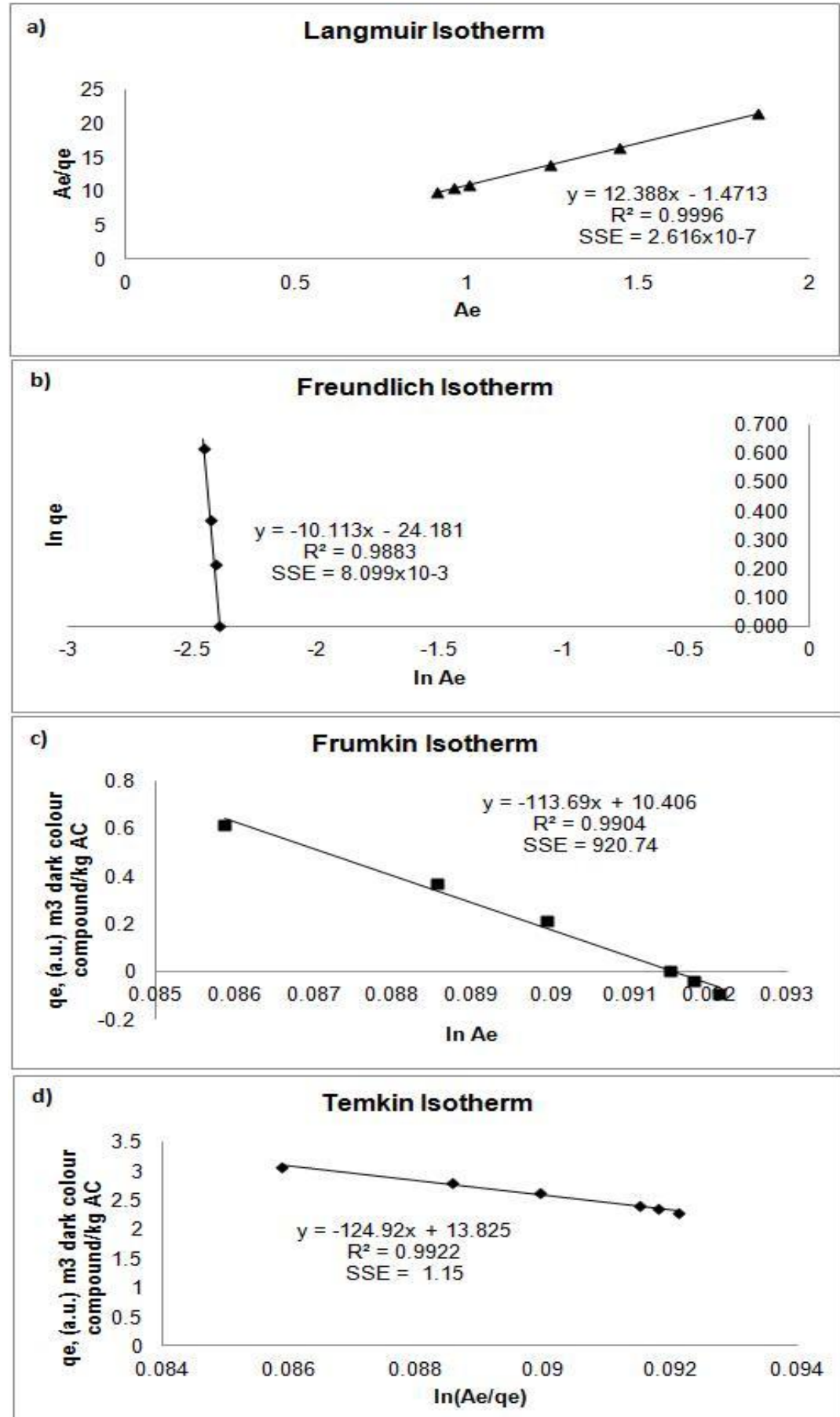

Figure 5 Graph of (a) Langmuir, (b) Freundlich, (c) Frumkin, (d) Temkin isotherm for dark colour compounds (linear regression analysis) on activated carbon at temperature $25^{\circ} \mathrm{C}$ 
Table 1 Langmuir, Freundlich, and Temkin constants for sorption of dark colour compound at different temperatures using the linear regression analysis

\begin{tabular}{|c|c|c|c|c|c|c|}
\hline Contact time (min) & 10 & 20 & 30 & 40 & $\mathbf{5 0}$ & 60 \\
\hline $\mathrm{A}_{\mathrm{o}}$ & 14.730 & 14.730 & 14.730 & 14.730 & 14.730 & 14.730 \\
\hline$A_{e}$ & 1.003 & 1.850 & 0.910 & 1.240 & 1.447 & 0.960 \\
\hline $\mathrm{q}_{\mathrm{exp}}$ & 0.09151 & 0.08587 & 0.09213 & 0.08993 & 0.08855 & 0.09180 \\
\hline $\mathrm{A}_{\mathrm{e}} / \mathrm{q}_{\mathrm{e}}$ & 10.960 & 21.545 & 9.877 & 13.788 & 16.340 & 10.458 \\
\hline $\ln \left(\mathrm{A}_{\mathrm{e}} / \mathrm{q}_{\mathrm{e}}\right)$ & 2.394 & 3.070 & 2.290 & 2.624 & 2.794 & 2.347 \\
\hline $\operatorname{lnq}_{\mathrm{e}}$ & -2.391 & -2.455 & -2.385 & -2.409 & -2.424 & -2.388 \\
\hline $\ln \mathrm{A}_{\mathrm{e}}$ & 0.003 & 0.615 & -0.094 & 0.215 & 0.369 & -0.041 \\
\hline
\end{tabular}

Table 2 Parameters in isotherm equation for the adsorption of dark colour compounds at $25^{\circ} \mathrm{C}$ with $\mathrm{AC}$ composition of $1: 1$

\begin{tabular}{lll}
\hline \hline Isotherm Models & Adsorption Parameters & Temperature: $\mathbf{2 5}^{\mathbf{0}} \mathbf{C}$ \\
\hline Langmuir & $\mathrm{Q}^{\mathbf{0}}$ & 0.08072 \\
& $\mathrm{~b}$ & -8.420 \\
& $\mathrm{R}$ & 0.9998 \\
& $\mathrm{SSE}$ & $2.616 \times 10^{-7}$ \\
\hline Freundlich & $\mathrm{K}_{\mathrm{f}}$ & 0 \\
& $1 / \mathrm{n}$ & -10.113 \\
& $\mathrm{R}$ & 0.9883 \\
& $\mathrm{SSE}$ & $8.099 \times 10^{-3}$ \\
\hline Frumkin & $\mathrm{K}_{\mathrm{T}}$ & 0.9125 \\
& $\mathrm{n}_{\mathrm{T}}$ & -113.69 \\
& $\mathrm{R}$ & 0.9904 \\
& $\mathrm{SSE}$ & 920.74 \\
\hline Temkin & $\mathrm{A}$ & 13.825 \\
& $\mathrm{~B}$ & -124.92 \\
& $\mathrm{R}$ & 0.9961 \\
\hline \hline
\end{tabular}

\subsection{CONCLUSION}

The decolourization device's optimum operating conditions for decolourizing $100 \mathrm{~mL}$ of cashew leaf extracts were found to be with an $\mathrm{AC}$ composition 1:1 (5 $\mathrm{g}$ of powdered $\mathrm{AC}, 5 \mathrm{~g}$ of granular $\mathrm{AC}$ ), at a temperature of $25^{\circ} \mathrm{C}$ for a contact period of $10 \mathrm{~min}$. Such conditions reduced $81 \%$ total phenolic content and retained $88 \%$ radical scavenging capacity of cashew leaf extracts. The design of this system best fits Langmuir isotherm which demonstrates monolayer coverage of the phenolic and darkcoloured compounds at the outer surface of AC. Hence, the use $\mathrm{AC}$ is a good alternative for removing phenolic and dark-coloured compounds from cashew leaf extracts. Based on the data obtained, it was found that cashew leaf extract decolourization can be manipulated to suit the needs of end-users by controlling the contact period. This newly designed decolourization device should be very suitable for other herbal extracts as well as it can be optimized by simply adjusting the ratio of granular and powdered activated carbon.

\section{Acknowledgement}

The author wishes to gratefully acknowledge the Institute of Bioproduct Development (IBD) and the Department of
Bioprocess Engineering, Universiti Teknologi Malaysia (Johor Bahru) for the facilitating in the project.

References

[1] Arslanoğlu, F. N., F. Kar, and N. Arslan. 2005. Adsorption of Dark Coloured Compounds from Peach Pulp by Using Granular Activated Carbon. Journal of Food Engineering. 68(4): 409-417. DOI: 10.1016/j.jfoodeng.2004.06.017.

[2] Soto, M. L., A. Moure, H. Domínguez, et al. 2008. Charcoal adsorption of Phenolic Compounds Present in Distilled Grape Pomace. Journal of Food Engineering. 84(1): 156-163. DOI: 10.1016/j.jfoodeng.2007.04.030.

[3] Sessa, D. J., F. J. Eller, D. E. Palmquist, et al. 2003. Improved Methods for Decolourizing Corn Zein. Industrial Crops and Products. 18(1): 5565. DOI: 10.1016/s0926-6690(03)00033-5.

[4] Carabasa, M., A. Ibarz, S. Garza, et al. 1998, Removal of Dark Compounds from Clarified Fruit Juices by Adsorption Processes. Journal of Food Engineering. 37(1): 25-41. DOI: 10.1016/S02608774(98)00075-2.

[5] Richard, D., M. d. L. Delgado Núñez, and D. Schweich. 2009. Adsorption of Complex Phenolic Compounds on Active Charcoal: Adsorption Capacity and Isotherms. Chemical Engineering Journal. 148(1): 1-7.

[6] Mukherjee, S., S. Kumar, A. K. Misra, et al. 2007. Removal of Phenols from Water Environment by Activated Carbon, Bagasse Ash and Wood Charcoal. Chemical Engineering Journal. 129(1-3): 133-142.

[7] Abas, F., N. H. Lajis, D. A. Israf, et al. 2006. Antioxidant and Nitric Oxide Inhibition Activities of Selected Malay Traditional Vegetables. Food Chemistry. 95(4): 566-573. DOI: 10.1016/j.foodchem.2005.01.034 
[8] Gaffar, R. A., N. E. S. Sazali and F. A. A. Majid. 2008. Colour Reduction And Anti-microbial Evaluation of Pre-treated Cashew Leaves Extract. Journal of Chemical and Natural Resources Engineering. 2(Special): 19.

[9] Abdul Gaffar, R., F. A. Abdul Majid, and M. R. Sarmidi. 2008. Tyrisonase Inhibition and Melanin Reduction of Human Melanocytes (Hemn-MP) Using Anacardium Occidentale L Extract. The Medical Journal of Malaysia. 63 Suppl A: 100-101.

[10] Konan, N. A. and E. M. Bacchi. 2007. Antiulcerogenic Effect and Acute Toxicity of a Hydroethanolic Extract from the Cashew (Anacardium occidentale L.) leaves. Journal of Ethnopharmacology. 112(2): 237-242. DOI: 10.1016/j.jep.2007.03.003.

[11] Odara Horta Boscolo, L. R. R. M. V. F., Luci de Senna Valle. 2010. An Ethnobotanical Survey as Subsidy for the Generation of Researches Related to Biotechnology. International Research Journal of Biotechnology. 1(1): 1-6.
[12] Bozin, B., N. Mimica-Dukic, I. Samojlik, et al. 2008. Phenolics as Antioxidants in Garlic (Allium sativum L., Alliaceae). Food Chemistry. 111(4): 925-929. DOI: 10.1016/j.foodchem.2008.04.071.

[13] Kadirvelu, K. and C. Namasivayam. 2003. Activated Carbon from Coconut Coirpith as Metal Adsorbent: Adsorption of Cd(II) from Aqueous Solution. Advances in Environmental Research. 7(2): 471-478. DOI: 10.1016/S1093-0191(02)00018-7.

[14] Caqueret, V., S. Bostyn, B. Cagnon, et al. 2008. Purification of Sugar Beet Vinasse - Adsorption of Polyphenolic snd Dark Coloured Compounds on Different Commercial Activated Carbons. Bioresource Technology. 99(13): 5814-5821. DOI: 10.1016/j.biortech.2007.10.009.

[15] Simaratanamongkol, A. and P. Thiravetyan. 2010. Decolourization of Melanoidin by Activated Carbon Obtained from Bagasse Bottom Ash Journal of Food Engineering. 96(1): 14-17. DOI 10.1016/j.jfoodeng.2009.06.033. 